\section{P-577性腺外胚細胞腫に対する末梢血幹細胞移植 併用化学療法の治療経験}

\author{
埼玉県立がんセンター 外科第二部1) 内科第一部2) \\ 化学療法部 ${ }^{3}$

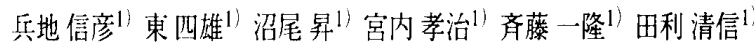 \\ 川東靖子 ${ }^{2 j}$ 坂下暁子 ${ }^{2 \dagger}$ 小林 泰文 ${ }^{2}$ 柵木信男 ${ }^{2 !}$ 金子安比古 $^{3)}$ \\ 【目的】1997年から難治性精巣腫腸の予後改善を目的に末梢血幹細 \\ 胞移植 (PBSCT) を併用した高用直化学痖法を施行している。 今 \\ 间は当センターで初回治療を行った4例の性腺外胚細胞堙鸠につ \\ いて臨床的検討を行った、【方法】対象は全例非セミノーマであ \\ $\eta$ ，原発は縦隔2例と後腹膜2例, Intemational Germ Cell Consensus分 \\ 類でintermediate群 1 例とpoor群 3例であった. First lineとしてVIP療 \\ 法を3コース行いGCSFを併用してPBSCを採取した，全例First line 3 \\ コースでは完全宽解 (CR) が得られず, PBSCT併用高用量化学療 \\ 法を1ないし2コース施行した，薬郕投与量はCBDCA $1500 \mathrm{mg} / \mathrm{m}^{2}$, \\ VP16 $1600 \mathrm{mg} / \mathrm{m}^{2}$, IFM $10 \mathrm{~g} / \mathrm{m}^{2}$ を基本とし, 残存腫場は外科的切除を \\ 行い病理組織学的効果判定を行った【結果】治療成績はCR3例 \\ (何れも pathological CR) とneutropenic enterocolitisによる治療関連死 \\ が1例であった．CRとなった3例には再発を認めていない【総括】 \\ 子後不良な性腺外胚細胞腫韵4例の初回治療としてPBSCT併用高 \\ 用量化学療法を行い治療関連死が1例認められたものの3例で良好 \\ な近接効果が得られ遠隔成績の向上が期待された。 \\ 胚細胞腫 化学療法 末梢血幹細胞移植
}

\section{P-579 進行精巣腫瘍における自家造血幹細胞移植 併用高用量化学療法}

\begin{abstract}
新潟大学 医学部 泌尿器科学教室 ${ }^{1 /}$ 厚生連中央綜合病院 新潟大学 医学部附属病院 高密度無菌治療部

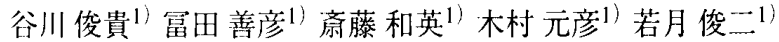
高橋公太 ${ }^{1)}$ 西山勉 ${ }^{2}$ 古川 達雄 ${ }^{3}$

我々は、進行精巣腫瘍13例に対し自家造血幹細胞移植併用高用量 化学療法を施行した。症例は、3才から42才までで、組織型は、

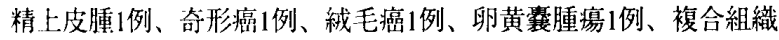
型9例であった。初発例の病期はIIB ：2、IIIA：1、IIIB2：4、IIIC： 2 例で、再発例は後腹膜のみ：1、後腹膜、縦隔、画肺、脳：1、 後腹膜、両肺：2例であった。高用量化学療法は、CBDCA 1 $1.6 \mathrm{~g} / \mathrm{m} 2 、$ VP- $161 \sim 1.6 \mathrm{~g} / \mathrm{m} 2 、$ IFM $10 \mathrm{~g} / \mathrm{m} 2$ またはCPA $1.0 \sim 1.2 \mathrm{~g} / \mathrm{m} 2 を 4$ 一 5日間に分けて投与し、2例にepi-ADM $100 \mathrm{mg} / \mathrm{m} 2$ を化学療法初日 に投与した。造血幹細胞移植は化学療法後2月開けて行い、G-CSF を $250 \mu \mathrm{g} \sim 300 \mu \mathrm{g} /$ 日を本梢血白血球数が $10000 / \mu$ 泤上になるまで 投·した。移植に用いた造血幹細胞は、自家骨䯣のみ3例、未梢 血幹細胞のみ8例、自家骨䯣己末梢血幹細胞併用が2例で、移植し たCFU-GM数は1.3×10E5 4.7×10E6/Kgであった。治療効果は、2 例で治療関連死となったが、CR3例、PR5例、NC3例で、PRの4例 とNCの3例で残存腫崵摘出術を行った。これら11例のうち1例は高 月是化学療法後5力月で腫瘍死し、10例は高用量化学療法後8力月 から8年:で生存中である。
\end{abstract}

進行精巣腫瘍 造血幹細胞移植 高用量化学療法

\section{P-578行性精巣腫晹に対するPBSCT併用超大量 化学療法の経験}

\begin{abstract}
杏林大学 泌尿器科 1 )

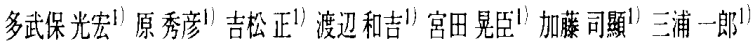

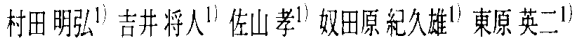

【目的】進行性精巣腫場に対するPBSCTを併用した超大量化学潦 法について検討した。【対象】対象は1995年以降、当科に扔いて精 巣腫瘍に対寸る導入化学療法 (BEP療法) 中にPBSCHを施行した7 例である。年齢は27 43歳、平均 31.4 歳で、病期分類はstage $2 B: 1$ 例、3A：1例、3B 2：4例、3C：1例であった。また、高位精巣摘 除術の病理診断はセミノーマガ2例、混合性肧緗胞腫瘍が5例であ つた。結果】PBSCT併用超大量化学療法を施行し得た5例全例が 現在cancer freeで経過観察中である。しかしPBSCT併用超大量化学 療法を施行し得なかった2例は、各々後腹膜りンパ節廓清術の摘 出組織内にviable cellが存在し、2例とも癌死の転帰をとった。

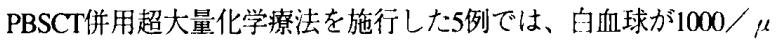
以上に回復するのに平均7.8日、血小板が50000/ $\mu$ 1以上に回復す るのに平均11.8日を要した。なお5例全例に平均62単位の血小板輸 血を要した。【まとめ】1.PBSCT併用超大量化学療法を施行した5 例は現在NEDである。2.PBSCT併用超大量化学療法を施行した5例 においてPBSCTに関連した重篤な副作用はみられなかった。
\end{abstract}

精巣腫痛 PBSCT
P-580 $\alpha_{1}$-アドレナリン受容体拮抗薬KMD -3 213 の摘出ヒ卜組織における前立腺選択 性

キッセイ薬品工業 薬理研究所 ${ }^{1}$ 福井医科大学 薬理学教 室 ${ }^{2)}$ 楅井医科大学 泌尿器科学教室 ${ }^{3)}$

村田 聡1) 谷口 隆信 ${ }^{2}$ 高橋 雅彦 ${ }^{3)}$ 岡田謙一郎 ${ }^{3)}$ 秋山克良 ${ }^{1)}$ 村松 郁延 2 )

【目的】前立腺肥大症に伴う排尿障害治療薬として開発された KMD-3213の摘出ヒト前立腺および血管系に対する親和性を結合 実験および機能実験を用いて検討し、その前立腺選択性を他の $\alpha$ 1-受容体拮抗薬である tamsulosinおよび prazosinと比較した。【方法】 手術操作等により得られた摘出と卜前立腺掞よび大動脈より調製 した膜分画を用いて、 [ $\left.{ }^{3} \mathrm{H}\right]$-prazosin㧍よび[ $\left.{ }^{3} \mathrm{H}\right]-\mathrm{KMD}-3213$ の結合実験 を行った。また、ノルアドレナリン収縮に対する拮抗作用につい て、摘出前立腺㧍よび腸間膜動脈標本を用いて機能面から評価し た。【結果】 [ $\left.{ }^{3} \mathrm{H}\right]$-prazosinは前立腺、大動脈ともに高親和性を示し た。 [ $\left.{ }^{3} \mathrm{H}\right]-\mathrm{KMD}-3213$ は前立腺に対して[ $\left.{ }^{3} \mathrm{H}\right]$-prazosinよりも高親和性を 示したが、大動脈にはほとんど結合しなかった。KMD-3213およ びtamsulosinは前立腺に対してprazosinよりも高親和性を示したが、 大動脈に対する親和性はprazosin >tamsulosin $>$ KMD-3213の順であ った。結合実験におけるKMD-3213の前立腺選択性はtamsulosinよ り20倍高いものであった。また、機能実験においてもKMD-3213 は腸間膜動脈よりも前立腺に対して100倍以上高親和性を示した。 【結論】ヒト組織においてKMD-3213はtamsulosin、prazosinと比べて 前立腺選択性に優れており、起立性低血圧など血管系に起团する 副作用の少ない薬剂となりうる可能性が示唆された。

alpha1-blocker BPH human 